\title{
Rotation Day reflections
}

\author{
By Joan M. Bechtel \\ Librarian \\ Dickinson College
}

\section{How collegial management works at Dickinson College.}

$\mathbf{T}$ he warm June sun streaming in the window lights up the dust specks stirred up as I houseclean the cabinets, files and desk of four years accumulated paper in preparation for returning to the "back room" tomorrow and the new chairperson's move into the front office. Grateful for the uninterrupted quiet of a summer Saturday when the library is closed, I can at last sort through the piles, mark for filing the important items, throw away the dross, and box up personal materials that I want to take with me to my new/old desk in Tech-

\section{Mission statements}

Mission Statements for College Libraries, the fifth publication in the CLIP (College Library Information Packet) series, is now available from ACRL. The new publication contains the results of a survey of 132 colleges, statements from regional accreditation associations on how library mission statements are used in the accreditation process and sample mission statements from 28 institutions.

The publication was compiled by Larry Hardesty, director of library services; Jamie Hastreiter, systems planning/serials coordinator; and David Henderson, instructional services/ collection management coordinator, all from Eckerd College, Saint Petersburg, Florida.

Mission Statements may be ordered from the ACRL Office, $50 \mathrm{E}$. Huron Street, Chicago, IL 60611-2795. The cost is $\$ 15$ for ACRL members and $\$ 20$ for non-members. ISBN 0-8389-69445 . nical Services. Yesterday, my final working day in the office, I finally completed the Chairperson's manual and the monthly Calendar of events and tasks for the incoming Chairperson. They may, in fact, be superfluous, as the new chairperson comes to the office well prepared by her years of active participation in the particular form of collegial management practiced at Dickinson. We both want this rotation, the third since initiation of the rotating chair nine years ago, to be as smooth as possible.

Like the floating particles of dust now glowing in the sun, bits and pieces of the events of the past four years are sparked in my memory by these preparations for Rotation Day. I recall most vividly those occasions when the librarians struggled to solve a problem or together celebrated some success. Collegial management as it has evolved in working together has forced new job descriptions and new relationships among the librarians and has resulted in greatly increased service to the educational program of the college. ${ }^{\downarrow}$ Today, however, as I prepare to change hats, I am aware that the po-

${ }^{1}$ For a fuller discussion of collegial management at Dickinson College, including shared job descriptions and improvements in library service since the reorganization, see Dorothy H. Cieslicki, "A New Status Model for Academic Librarians," Journal of Academic Librarianship 8 (May 1982):76-81; Joan Bechtel, "Collegial Management Breeds Success," American Libraries, November 1981; and "Academic Professional Status: An Alternative for $\mathrm{Li}$ brarians," Journal of Academic Librarianship, November 1985 (in press). 


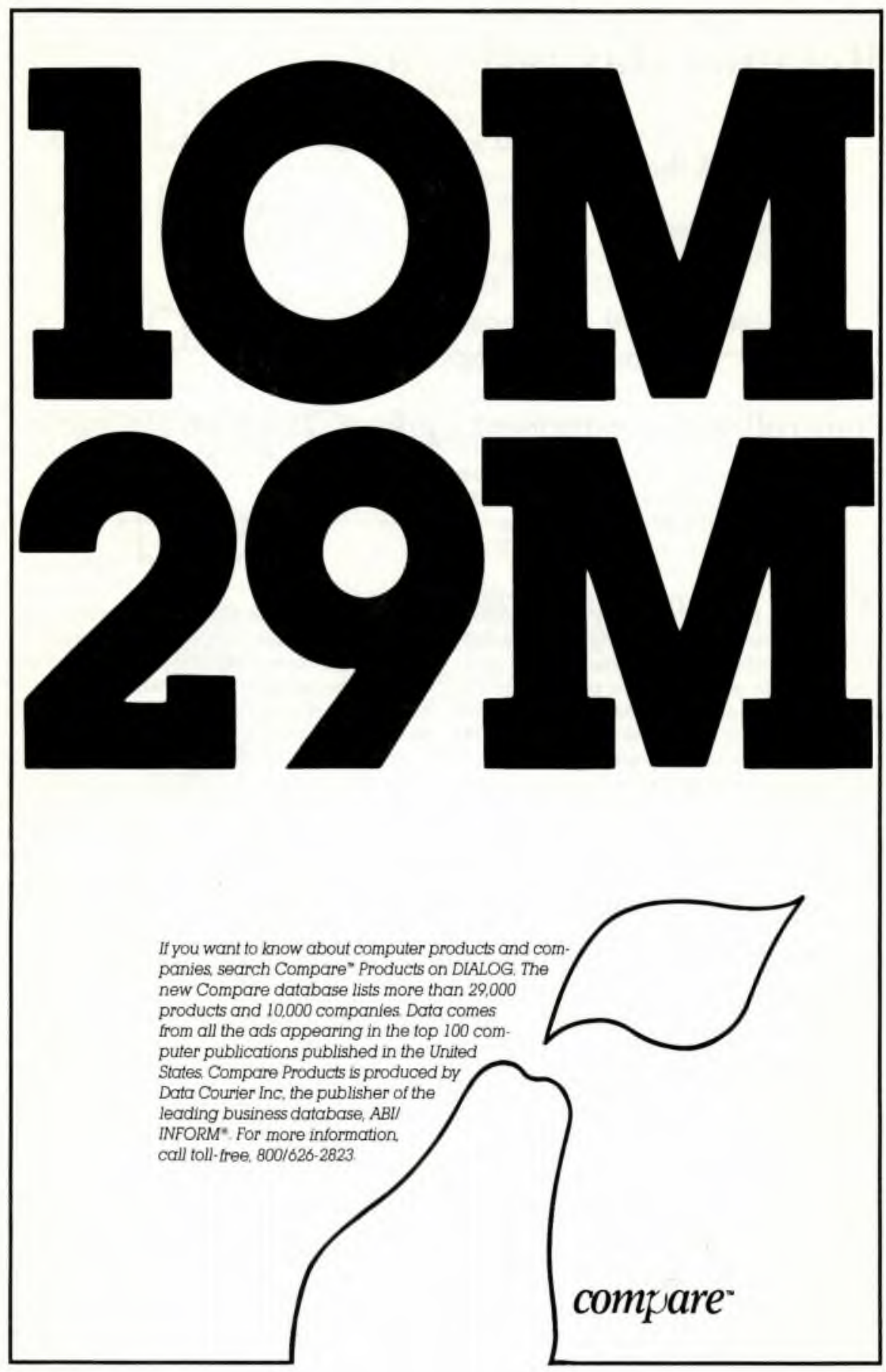


sition I have filled for the past four years is very different from that of the usual Head Librarian. Rather than directing and supervising the work of the library, I have served chiefly as a facilitator, an interpreter, and a coordinator as well as a leader.

In the role of facilitator I was responsible for making sure that the other seven librarians and the thirteen support staff members were able to do their jobs at a high performance level and were free to stretch and to grow. This has involved counseling with individual staff members, chairing staff meetings, serving as an advocate in the college administration for individuals and groups within the staff and in general providing the support the staff needs to do their jobs efficiently and well. Sometimes this has necessitated making a difficult, negative evaluation, but more often it has required the pleasant task of noting with appreciation the good work of individuals or groups.

A major responsibility of the Chairperson has also been and will continue to be to act as an interpreter of the library's.mission and goals to the staff itself, as well as to the administration, the faculty, students, alumni and to the larger library world. The interpretation and discussion of these issues not only serve to inform the library's constituencies, but also serve as the occasions for all to reflect upon the appropriate mission of the library and to sharpen and adjust the goals as the direction of the academic program changes and expands.

Coordination of staff planning, both long and short range, and of the day to day activities of the staff consumed a large portion of the chairperson's time. This has included everything from coordinating the movement of 30,000 volumes to off-site storage to installation of new computer equipment, from preparing draft budgets, reports to college committees and agendas for weekly staff meetings to dealing with the Buildings and Grounds department when the windows had not been washed in two years.

More often than not, facilitating the work of the department, interpreting library services and concerns, and coordinating all the activities of the department have necessitated embracing other peoples, priorities and agendas as if they were my own. Promoting my concerns and encouraging the college and the staff to address them has been a continual struggle and one that has demanded genial, tactful persistence.

Lastly, the office of Chairperson is one that requires the exercise of leadership. However, the leadership that is required and that is appropriate to the office and to collegial management is one characterized by discussion, consultation and persuasion rather than by fiat or directive. This sort of leadership is continually exercised as one goes about the day to day activities of counseling, advising, coordinating, report writing, chairing and attending meetings, etc., and is as important for the chairperson as it is for the rest of the staff. While this style of leadership may appear to be time con- suming and cumbersome, it is well worth the effort. One's own ideas are continually honed and refined in discussion with others and, even more importantly, the ideas, opinions and imaginations of one's colleagues are readily available resources for the improvement of library service.

The temptation, however, to succumb to the lure of a more autocratic role is never far away.

\section{Librarians work as}

\section{partners, not competitors.}

The library world tends to view one as a Head $\mathrm{Li}$ brarian; most mail is addressed to the "Head," colleagues from other libraries assume the chairperson is really a "Head," and even faculty members, students or library staff people sometimes assume an inappropriately hierarchical, dictatorial role for the chairperson. One is occasionally brought up short by one's own propensities to enjoy deference granted or services performed or suggestions accepted without, at least, minimal examination. The office of chairperson, both for one's individual health and for the good of the library, requires continual rejection of the role of "boss" in favor of promoting the notion and reality of colleagueship. In the last few days before Rotation Day several people commented appreciatively on the work of the library in the last few years. The most gratifying, however, came when one support staff member commented, "I never felt it was a boss/worker relationship, but more like a partnership."

Collegial management in the Dickinson College library, including both a structure in which all the librarians function as equals with a rotating Chairperson Position, has had a major impact upon the self-image of all the librarians and this in turn has influenced the character and quantity of library service and the position of librarians at the college. Because all the librarians share in decision making, long and short range planning, and administration of the library and because all the positions involve a wide variety of library activities and services, the librarians now work as partners rather than competitors. No longer does the blue wall separating the technical services area from the rest of the library serve as a stark reminder of the division and contention between catalogers and reference librarians. All see themselves primarily as educators, librarian educators, who are confident of their roles and worth as colleagues of and with classroom faculty. The result is that all eight librarians, not just the Chairperson, are actively involved in the educational process. Collegial management including the rotation of the office of chairperson has 
freed librarians from the necessity of competition for the few positions in the middle or at the top of the hierarchy and has empowered them to work together for the advancement of the goals of the library. Such a structure provides every librarian, not just the director, with responsible, challenging and fully professional positions and the opportunity, after a successful, six year probationary period, to serve in the position of chairperson. Even more importantly for the office and for the work of the library, such rotation provides fresh leadership and new perspectives on a continuing basis. The result is that the released energy and creativity have resulted in productivity that far outweighs the time-consuming aspects of democratic organization.

In short, all the librarians are professionally healthier than they were before reorganization and are more energetic, enthusiastic and excited about their profession than in most other libraries I know. Ideas originating with all eight librarians, not just one, abound; the interplay and exchange of opinion and the efforts to resolve disagreements add to the generation and growth of new ideas. Services are expanding and improving in quality in spite of the alleged cumbersomeness and time-consuming aspects of collegial management. Clearly the energy and creativity released by the sharing of responsibility and authority have more than outweighed the alleged negative aspects of the more deliberate pace of collegial organization
Finally, I look forward with keen anticipation to the next few years as a member of the Dickinson library staff. I am confident that my professional life in the library will continue to be stimulating and challenging as I move out of the front office and into a position that includes cataloging, serving on the automated catalog development team, service at the reference desk, liaison to the religion, philosophy, geology and Judaic studies departments, and bibliographic instruction to students in those departments and to five freshman seminars. Again, contrary to the weight of much of library opinion, job satisfaction and prestige do not necessarily depend upon being the top administrator in a library. In this library all positions are challenging and responsible; all demand energy, creativity and commitment. Rather than regret over what could be perceived as a demotion and loss of prestige, I look forward to having more think time as I am relieved of the need to deal with the nitty gritty of keeping the library functioning well. No longer will I have to worry about the faulty alarm system, the flooded basement, the staff vacation schedule, etc Rather than dismay at the loss of position and power, I anticipate with pleasure the opportunity to have more time to think about important issues and problems in depth, to pursue ideas rather than answers to the everyday questions of library operation. The changes I anticipate are, however, ones of emphasis rather than fundamental because, along with the other seven librarians, I will con-

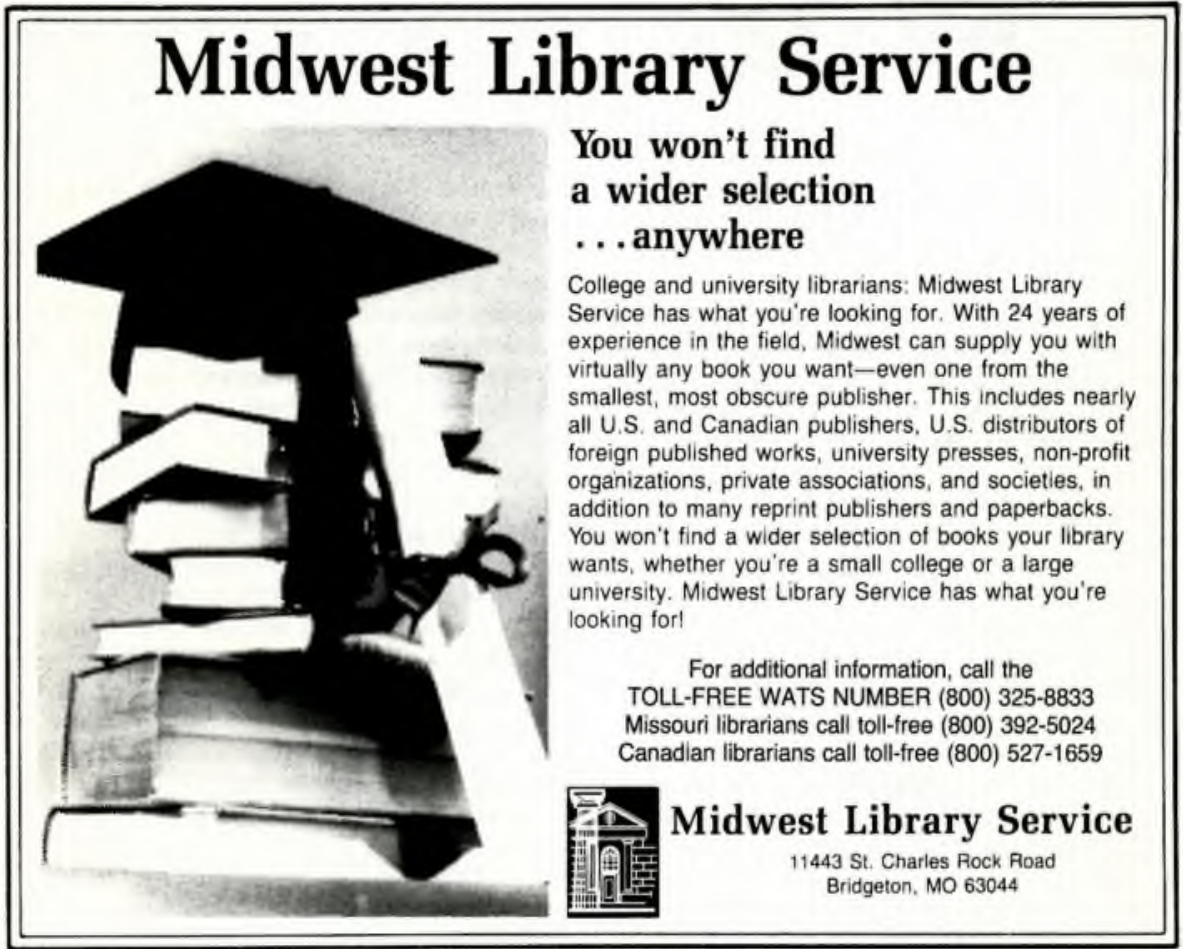


tinue to have responsibility for long range planning, decision making and some administration of the library.

The sun/dust fireworks filling the now almost empty office, while inadequate to the task, provide a festive celebration of Rotation Day, a day noteworthy in the library world for its liberating effects. In fact, in some measure, it is the Bastille Day or the 4 th of July for the Boyd Lee Spahr Library. In the same way that people celebrated the fact that one social class was no longer subservient to another or that the colonists were no longer subject to the king, librarians on Rotation Day celebrate freedom from dehumanizing hierarchy and debililating competition and division. When all librarians share equally the responsibilities and rewards of librarianship, they are free to realize their full potential; they become fully human. Rotation Day is, then, an appropriate occasion for celebrating the boundless potential, individual and corporate, of librarians to contribute to education and to the preservation and growth of knowledge.

\section{ACRL continuing education courses}

\section{at the Midwinter Meeting}

The Association of College and Research Libraries will sponsor four continuing education courses at the ALA Midwinter Meeting in Chicago. Advance registration by December 23,1985 , is required. A late registration fee of $\$ 15$ will be charged.

A Certificate of Completion will be awarded participants in each course. Successful completion of 10 contact hours of continuing education is equal to one Continuing Education Unit (CEU). ACRL maintains a CEU record for each participant.

To register, send in a completed registration form to Sandy Donnelly, ACRL/ALA, $50 \mathrm{E}$. Huron Street, Chicago, IL 60611. Details of the courses follow:

\section{Performance Evaluation: \\ A Results-Oriented APPROACH}

CE 106 will introduce participants to the concept of performance evaluation based on performance goals and results-oriented evaluation. This includes explanation of different approaches and purposes for evaluation; review of how a goalsbased performance system works; practice writing performance goals; discussion of how to improve a poor evaluation system; meeting conflict in evaluation interviews; and how to make evaluation a developmental experience for the supervisors and the employee.

Instructor: Lucy Cohen, Manager of Personnel and Payroll, University of Michigan Libraries.

Date: Friday, January 17, 9:00 a.m. $-5: 00$ p.m.

Fee: ACRL members $\$ 95$; non-members $\$ 135$.

CEUs: $7 \mathrm{CEU}$.

\section{Operating and Marketing Fee-Based SERVICES IN ACADEMIC LIBRARIES: A SMall Business ApProaCH}

CE 108a provides information to enable administrators and librarians from academic libraries and especially operating managers with the tools to critically analyze fee-based service operations. Participants are urged to bring any existing service brochures, price schedules, policy statements and business plans with them to the program. These documents will be especially useful during the working portion of the program.

Instructor: Barbara Stump, Director, Regional Information and Communication Exchange, Rice University Library.

Date: Friday, January 17, 9:00 a.m. $-5: 00$ p.m. Fee: ACRL members \$95; non-members \$135. CEUs: 7 CEU.

\section{Imphoving Job Performance: STRATEgIES For SUPERVISORS}

CE 112 will help librarian-supervisors create a climate for motivation, define job competencies, set performance standards, address performance problems and improve work effectiveness of their staff. This course is intended for librarians who are first-line supervisors or middle managers. Past participants to CE 101 note: the material presented in this course will build upon the knowledge and skills developed in ACRL CE 101 Librarians as supervisors.

Instructor: Maureen Sullivan, Head of Personnel, Yale University Library.

Date: Friday, January 17, 9:00 a.m.-5:00 p.m Fee: ACRL members $\$ 95$; non-members $\$ 135$. CEUs: 7 CEU.

\section{Creative Approaches to Video for BIBLIOGRAPHIC INSTRUCTION}

CE 206-It is estimated that over 600 academic librarians have produced videotapes for bibliographic instruction. This workshop examines uses of video, critical production issues, and a financial comparison of various media products. Many examples of library video products will be examined. In addition, creative problem solving techniques will be applied to the process of developing a videotape project. A number of exercises designed to enhance creative potential will be conducted.

Instructor: Thomas McNally, Head Circulation 